\title{
Erratum to: Citizenship status and language education policy in an emerging Latino community in the United States
}

\author{
Ariana Mangual Figueroa
}

Published online: 24 April 2014

(C) Springer Science+Business Media Dordrecht 2014

\section{Erratum to: Lang Policy (2013) 12:333-354 \\ DOI 10.1007/s10993-013-9275-x}

The original version of the article has been published with certain errors that are corrected below:

In the reference list, Professor Evans name was spelled as Evns. The corrected reference is given below:

Evans, B. A. \& Hornberger, N. H. (2005). No child left behind: Repealing and unpeeling federal language policy in the United States. Language Policy, 4(1), 87-106

The name of Professor Goetz was misspelled as Goetze in both the text and reference. The correct reference should be as follows:

Goetz, J., \& LeCompte, M. (1981). Ethnographic research and the problem of data reduction. Anthropology \& Education Quarterly, 12(1), 51-70

Due to an oversight, Professor Johnson's paper was omitted from the final reference. Please note that where Johnson's paper is mentioned in the text this refers to:

Johnson, D. C. (2009). Ethnography of language policy. Language Policy, 8, 139-159.

The online version of the original article can be found under doi:10.1007/s10993-013-9275-x.

\footnotetext{
A. Mangual Figueroa

A. Mangual Figueroa ( $\square)$

121 Saint Marks Place \#3, Brooklyn, NY 11217, USA

e-mail: amf@gse.rutgers.edu
}

Rutgers University, 10 Seminary Place, New Brunswick, NJ 08901, USA 